\title{
Research on the Application Effect of Process Teaching Method Based on AHP and Fuzzy Comprehensive Evaluation
}

\author{
Lihua Yang \\ Dongying Vocational College, Dongying, China \\ lihua_yang1@163.com
}

Keywords:process method; fuzzy comprehensive evaluation; effect analysis; membership degree; evaluation matrix; AHP comprehensive evaluation

\begin{abstract}
According to the writing teaching method to carry on the analysis in the college English teaching process in. Describing teaching mode and teaching part of process writing teaching method in detailed. Through investigation and analysis, it is conclude that satisfaction degree of process writing teaching for the college students, as is shown in statistical results. Most of the students are satisfied with process writing teaching method. Then evaluate the process writing approach to three levels by using the fuzzy evaluation method. Carrying on the comprehensive evaluation to process writing teaching method by using the multi-level comprehensive evaluation technology, the conclusion that the present this kind of teaching method is suitable to the college English teaching, with the ultimate effect is good. Finally, specific analysis of the advantages and disadvantages in process writing teaching, provide certain reference to teachers in the process writing teaching.
\end{abstract}

\section{Introduction}

In the English study need to melt English listening, composition reading and essay writing for a whole to learn, but at present lack of understanding on English writing training in college English teaching seriously, causing the college students merely grasp of the English language is limited to listening and speaking and unable to good writing. Therefore, the need for college English teaching reform, the goal is to improve the students' English writing teaching effect, and this effect mainly displays in the following several aspects[1,2]: (1) Changing the traditional concept of English writing teaching, and puts forward the new concept, optimizes the college English writing teaching, improves teaching efficiency; (2) Boosting students' learning initiative and improve their English writing participation and interest level, it blend into the cooperative learning and their knowledge construction in the process of understanding. Therefore, the process writing teaching method lead into college English teaching which plays an important role.

\section{The process writing teaching theory}

The process writing teaching methods mainly emphasized on the importance of the writing in the process of teaching or learning, it is the views that different with the results theory. The core of process writing teaching is to pay attention to the process of writing; this method defined the continue writing process as a kind of repeated circulating process which had the find meaning[3]. In the perspective of the process writing teaching method, it wrote and learned from the original ideals. After data consult and collection, arrangement and the accomplish of final writing formed a complete study, the purpose for the combination of learners' thinking and writing process, to improve our writing skills and writing ability through constant writing. At the same time, the basis of process writing teaching theory mainly manifested on communication theory, and the whole writing process regarded as a group mutual exchanges and communication, was a kind of teamwork behavior.

The process writing teaching method is that regard the writing process as a dynamic learning change process, mainly focused on the writing process in learning. Generally the process that learning to writing, university students carried on all kinds of communicative activities such as consultation, communication, evaluation before writing, in writing and after writing with other students, from another angle to improve their communication skills and express ability[4]. In general, the process writing teaching method divided the writing process into material information collection, 
writing plan brake, implement stage, the evaluation of writing achievement and mutual adaptation, this kind of method emphasized on the link of students' thinking conception, writing ability, evaluation ability and modify finalized level. And teachers in the whole writing process merely had done the writing organization and guidance, made students' learning to become self learning process, and made the full understanding and internalized absorption for writing process, to achieve the purpose for efficient teaching.

At present, many scholars and teachers who had many years of experience summarized some process writing teaching practice mode to provide teachers' application.

From Figure 1, it is known that the writing teaching process mainly includes six steps prewriting, writing outline, writing content first draft, content modification, and content finalized and mutual share and so on[5]. In which, in the prewriting stage, mainly cultivated the student's own independent thinking ability; In writing the outline stage, should fully help the students to complete expression of their own thinking; modify process was self improvement and re-know stage, paid attention to detail, pursued on perfect; finalized and then shared their finished products, had experienced a sense of accomplishment.

\section{The investigation and analysis of process writing teaching method in college English teaching}

According to the writing teaching satisfaction survey for college student on the process writing teaching method $\mathrm{s}$ in colleges English teaching. This provided seven options, respectively not unusual satisfied, not satisfied, a few not satisfied, general, a little satisfied, satisfied, unusual satisfied.

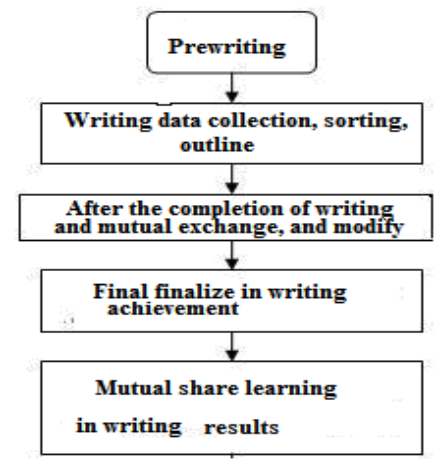

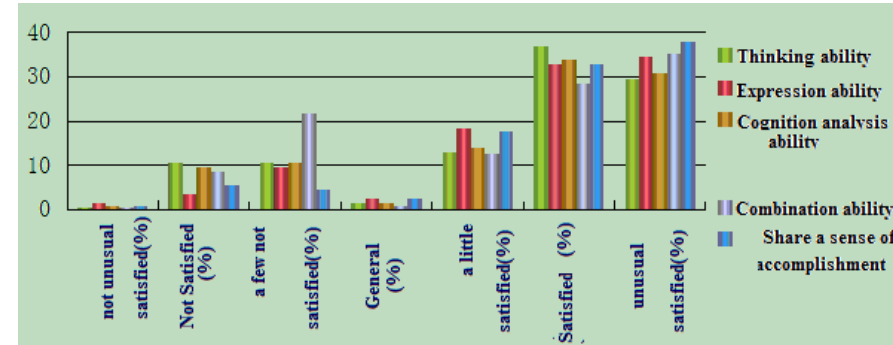

Figure 2. The satisfaction scale map of the process writing teaching method in college English

Figure 1. The mode in process writing teaching method

\section{The comprehensive evaluation model for process writing teaching effect}

Fuzzy evaluation got fuzzy information to quantified, reasonable selected factors shareholding, the factors are quantitatively evaluated. Through the process of writing teaching for multistage fuzzy comprehensive evaluation of the English teaching effect, because of process writing teaching process elements included five aspects, so we only had considered five aspects that influenced process writing teaching process English teaching scheme, as shown in table 1. Weights were determined by the student to the whole English teaching satisfaction.

TABLE I. THE SATISFACTION SURVEY DATA SHEET OF PROCESS WRITING TEACHING METHOD IN COLLEGE ENGLISH TEACHING

\begin{tabular}{|c|l|l|l|l|l|c|c|}
\hline & $\begin{array}{c}\text { not unusual } \\
\text { satisfied(\%) }\end{array}$ & $\begin{array}{c}\text { Not } \\
\text { Satisfied } \\
\mathbf{( \% )}\end{array}$ & $\begin{array}{c}\text { a few not } \\
\text { satisfied } \\
\mathbf{( \% )}\end{array}$ & $\begin{array}{c}\text { General } \\
\mathbf{( \% )}\end{array}$ & $\begin{array}{c}\text { a little } \\
\text { satisfied } \\
\mathbf{( \% )}\end{array}$ & $\begin{array}{c}\text { Satisfied } \\
\mathbf{( \% )}\end{array}$ & $\begin{array}{c}\text { unusual } \\
\text { satisfied(\%) }\end{array}$ \\
\hline Thinking ability & 0.6838 & 10.6562 & 10.5267 & 1.6278 & 13.1206 & 37.0426 & 29.6232 \\
\hline Expression ability & 1.5431 & 3.6627 & 9.7214 & 2.6262 & 18.5246 & 32.7834 & 34.6322 \\
\hline Cognition analysis ability & 0.7483 & 9.6372 & 10.5267 & 1.6156 & 14.1172 & 33.7892 & 30.7732 \\
\hline Combination ability & 0.5372 & 8.5378 & 21.6261 & 0.7189 & 12.6216 & 28.4523 & 35.1351 \\
\hline $\begin{array}{c}\text { Share a sense of } \\
\text { accomplishment }\end{array}$ & 0.7734 & 5.6738 & 4.6823 & 2.6187 & 17.7724 & 32.8321 & 37.7231 \\
\hline
\end{tabular}

(1)The comprehensive evaluation in original level of process writing teaching effect

The factors comprehensive evaluation in process writing method: 
First of all, it made sure the evaluation factors, the influence elements of process writing teaching had three, was composed by[6]:

$\mathrm{V}=\{$ writing (v1), modified (v2), finalized (v3) $\}$;

There are four evaluation sets, thus evaluation theory field in composition were

$\mathrm{U}=\{$ no satisfaction (a1), general (a2), satisfaction (a3), very satisfied (a4) $\}$

Secondly to determined the membership of factors: no satisfaction accounted for 7\%; General accounted for 13.2\%; Satisfaction accounted for 42.5\%; Very satisfied accounted for $37.3 \%$.

The "writing" membership said: v1 $=(0.15,0.524,0.226,0.10)$

"Modify" said: v2 $=\left(\begin{array}{lll}0.24, & 0.66,0.235,0.2)\end{array}\right.$

"Finalized" for: v3 $=(0.36,0.365,0.41,0.14)$

The evaluation matrix in composition[7]

$$
R_{1}=\left[\begin{array}{llll}
0.15 & 0.524 & 0.226 & 0.10 \\
0.24 & 0.66 & 0.235 & 0.2 \\
0.36 & 0.365 & 0.41 & 0.14
\end{array}\right]
$$

The weight number got to normalization, namely $0.3+0.3+0.4=1$

Constituted of a fuzzy vector for factor set $\mathrm{V}=\left(\begin{array}{lll}0.3 & 0.3 & 0.4\end{array}\right)$

Available for comprehensive evaluation[8]

$$
A_{1}=R_{1} V_{1}=\left(\begin{array}{lll}
0.3 & 0.3 & 0.4
\end{array}\right)\left[\begin{array}{llll}
0.15 & 0.524 & 0.226 & 0.10 \\
0.24 & 0.66 & 0.235 & 0.2 \\
0.36 & 0.365 & 0.41 & 0.14
\end{array}\right]=\left[\begin{array}{llll}
0.164 & 0.74 & 0.086 & 0
\end{array}\right]
$$

(2) The secondary level comprehensive evaluation of process writing teaching effect

"Elements details" secondary level comprehensive evaluation said:

The boundary marker, prewriting, writing outline, writing content first draft, content modification, content finalized and mutual share and so on six steps in the element details constituted of the secondary comprehensive evaluation system for English teaching scheme. In which, took boundary marker and expand, extension as an important weight. By the weight number of "boundary marker" "expansion extension" constituted of a fuzzy vector B1 $*=(0.40 .6)$. It concluded the comprehensive evaluation results

$$
B_{1}^{*}=A_{1}^{*}\left[\begin{array}{l}
B_{1} \\
B_{2}
\end{array}\right]=\left(\begin{array}{ll}
0.4 & 0.6
\end{array}\right)\left[\begin{array}{llll}
0.262 & 0.74 & 0.076 & 0 \\
0.3 & 0.435 & 0.075 & 0
\end{array}\right]=\left[\begin{array}{llll}
0.223 & 0.71 & 0.085 & 0
\end{array}\right]
$$

The "writing" comprehensive evaluation results was[9]

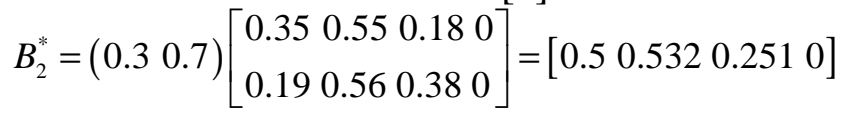

By the same token "modify" comprehensive evaluation results was

$$
B_{3}^{*}=\left(\begin{array}{ll}
0.3 & 0.7
\end{array}\right)\left[\begin{array}{llll}
0.31 & 0.2445 & 0.4325 & 0 \\
0.5815 & 0.155 & 0.4325 & 0
\end{array}\right]=\left[\begin{array}{lll}
0.246 & 0.5172 & 0.3485
\end{array}\right]
$$

By the same token "finalized" comprehensive evaluation results was

$$
B_{4}^{*}=\left(\begin{array}{ll}
0.3 & 0.7
\end{array}\right)\left[\begin{array}{cccc}
0.32 & 0.456 & 0.34 & 0 \\
0.51 & 0.23 & 0.36 & 0
\end{array}\right]=\left[\begin{array}{llll}
0.351 & 0.3542 & 0.537 & 0
\end{array}\right]
$$

(3) The three-level hierarchy comprehensive evaluation of process writing teaching effect

The elements details content in process writing method acted as fuzzy vector of comprehensive evaluation in English teaching scheme

$$
B^{*}=\left[\begin{array}{lllll}
0.15 & 0.15 & 0.2 & 0.3 & 0.2
\end{array}\right]
$$

The comprehensive evaluation results

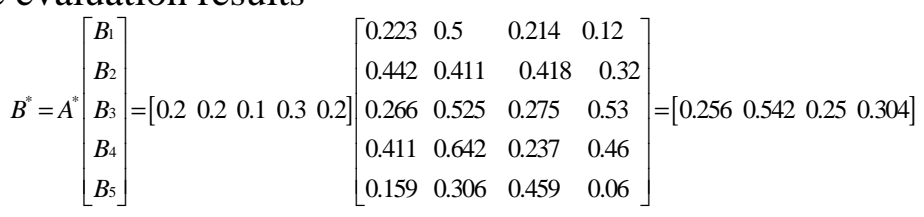

The above three comprehensive evaluation results showed that the students felt very good to the evaluation effect of process writing teaching, perceived more satisfied. 


\section{The characteristics of process writing teaching method in college English teaching}

At present analyzing the main characteristics of process writing teaching method on the basis of the summary in college English teaching are[10]:

(1) It had students understood my own writing process in English learning. English learning emphasized on the writing process, strengthened the education on students' English writing level, made its profound master on main steps of process writing in English learning, such as prewriting, writing outline, writing content first draft, content modification, content finalized and mutual share and so on, so as to make sure that the students got less detours or wrong in learning English writing.

(2) Which is helpful to stimulate the students' learning initiative and interest, is benefit to set up the self-confident in English learning; cultivating students' English writing self concept, the preparation of ideological contents before writing, trained their writing ideation, and ensured that the writing is something to write and emotional. At the same time, the students' communication and modification also ensured that students' oral English and ability cultivation, in the process of the discussion, improved their English level and interests in subconscious mind, increased students' learning English confidence.

(3) The benefit for promoting the development of students' thinking ability. In the English learning process writing teaching mode could help students' data access, data collection ability, through the accumulation of thinking, active exploration and research, fully mobilized students' learning initiative, became the inner motive power of self learning.

(4) Its advantage for providing the student's own initiative. Team writing teaching in the process of writing teaching, namely the multiple communication on the model of the students were given priority, the teachers were auxiliary. This model might stimulate the students' enthusiasm of learning from each other and mutual cooperation spirit to progress together. At the same time, it stimulated the students' self improvement, identifying and mutual harmonious competition study atmosphere.

\section{Conclusion}

In conclusion, the main process writing teaching is to require the students insist on a long time of writing exercise, combining study method and its own characteristics for study to get better effect. Process writing teaching method in colleges' English teaching process not only expand the teachers writing teaching theory, but also stimulate the students' study initiative and enthusiasm. As much as possible to provide the time and space to increase the understanding on writing contents and meaning of this method in English learning for the students, and to further improve the level and the students' expression and writing level. Therefore, the great advantages of process writing teaching method still need to further promote, and at the same time, flexible and reasonable reference to previous process writing teaching practice experience, and strive to writing teaching scientific, systematic, in order to improve the effectiveness of the writing teaching in our country.

\section{References}

[1] LiuWeihua, ZhangSheqiang, ChenHongtao. The construction on students' satisfaction survey evaluation system university thought politics theory teaching.Journal of cultural and educational material, 2007 (5):35-38.

[2] ShiYayi. Application on linear structural equation model evaluation index. China hospital statistics, 2011 (4):54-59.

[3] ShiHansheng. The role of language sense in English teaching. Polytechnic higher education research, 2010 (1): 118-119.

[4] Zhang Ruifang. The cultivation of language sense in English teaching [J]. Journal of JiNing college, 2012 (2): 68-71.

[5] WangYuePing. The characteristics of language sense. Journal of FuYang normal college: social science edition, 2012 (5): 60- 62.

[6] ZhouJian. The second language teaching should be guidance by develop language sense. Language and translation, 2008 (1): 53-57. 